\title{
Taft-Hartley Pre-emption in the Area of NLRB Inaction
}

\author{
Mathew O. Tobriner* and Joseph R. Grodin**
}

During the past decade the Supreme Court of the United States has mapped out an area from which, it has held, the Taft-Hartley Act ${ }^{1}$ excludes state regulation of labor-management relations. While a state may keep the public peace by such measures as enjoining ${ }^{2}$ and granting damages ${ }^{3}$ for violence on the picket line, it may not, at least as to employment relations over which the National Labor Relations Board would assert jurisdiction, enjoin activity either protected under section $7^{4}$ or proscribed as an unfair labor practice under section $8^{5}$ of the act. The exact boundaries of the area from which states are thus excluded are not yet fixed. ${ }^{6}$ It is not clear, for example, to what extent, if any, a state may grant damages for injury or loss resulting from activity it may not enjoin, ${ }^{7}$ or enjom activity which the

* Member, San Francisco Bar.

** Member, San Francisco Bar.

161 STAT. 136 (1947), as amended, 29 U.S.C.A. $\$ \S 141-88$ (1956). (All section references in text and notes are to Taft-Hartley Act unless otherwise indicated.)

3 United Automobile Workers v. Wisconsin Employment Relations Bd., 351 U.S. 266 (1956).

3 United Constr. Workers v. Laburnam Constr. Corp., 347 U.S. 656 (1954).

4 Section 7 protects the right of employees to engage in "concerted activities." See text at note 34 infra. The Supreme Court has held such activities protected against governmental as well as employer interference. Amalgamated Ass'n of Street, Electric Railway Employees v. Wisconsin Employment Relations Bd., 340 U.S. 383 (1951); International Union of United Automobile Workers, CIO v. O'Brien, 339 U.S. 454 (1950); Hill v. Florida ex rel. Watson, 325 U.S. 538 (1945) ; see Weber v. Anheuser-Busch, Inc., 348 U.S. 468 (1955).

5 Garner v. Teamsters Union, AFL, 346 U.S. 485 (1953); Building Trades Council v. Kinard Constr. Co., 346 U.S. 933 (1953) ; see Plankinton Packing Co. v. Wisconsin Employment Relations Bd., 338 U.S. 953 (1950).

6 For analyses of the uncbarted areas see Brody, Federal Pre-emption Comes of Age in Labor Relations, 5 LAB. L.J. 743 (1954); Cox, Federalisnt in the Law of Labor Relations, 67 Harv. L. REv. 1297 (1954); Glushien, Federal Pre-emption in Labor Relations, 15 FED. B.J. 4 (1955) ; Hays, Federalisn and Labor Relations in the United States, 102 U. PA. L. REV. 959 (1954); Isaacson, Labor Relations Law: Federal v. State Jurisdiction, 42 A.B.A.J. 415 (1956) ; Preston, Federal Pre-emption in Labor Relations, a Reply to Professor Cox, 36 CEx. BAR REc. 121 (1954); Rose, Federal-State Conflicts in Labor Injunction Cases, 15 FED. B.J. 16 (1955) ; Rose, Garner v. Teamsters: The Supreme Court and Private Rights, 40 VA. L. REv. 177 (1954); Roumell and Schlesinger, The Pre-emption Dilemma in Labor Relations, 18 U. DET. L.J. I7 (1955); Shute, State v. Federal Jurisdiction in Labor Disputes: The Garner Case, 19 Mo. L. Rev. 119 (1954); Turnbull, Federal-State Jurisdictional Problems, 7 LAB. L.J. 5 (1956); Wollett, Taft-Hartley and State Power to Regulate Labor Relations, 30 WAsE. L. REv. 1 (1955).

7 See United Constr. Workers v. Laburnam Constr. Corp., 347 U.S. 656 (1954) (state court has jurisdiction to grant damages for violence); Benz v. Compania Naviera Hidalgo, S.A., 233 F.2d 62 (9th Cir. 1956) (federal district court has jurisdiction to grant damages in strike for improper objectives); Dallas Gen. Drivers v. Wamix Inc., 281 S.W.2d 738 (Texas 1955) (semble). 
act neither protects nor prohibits. ${ }^{8}$ But however the Supreme Court decides these questions, it is apparent that the area closed to state action is a sizable and important one.

This same decade, however, witnessed a significant countercurrent in the form of a revision of the Board's "yardsticks" for determining whether it would exercise the jurisdiction granted to it by the act. Although the Board has power to regulate unfair labor practices "affecting commerce" -a term interpreted by the Supreme Court as exhausting congressional power to regulate commerce ${ }^{10}$ - the Board almost since its inception has declined to assert its power over smaller localized operations initially on the ground that they do not substantially affect interstate commerce ${ }^{11}$ and later on the ground that it would not "effectuate the policies of the Act" to assert jurisdiction over them. ${ }^{12}$ In 1950 the Board codified certain of its previous case-by-case jurisdictional decisions into a set of yardsticks based upon the volume and kind of operation of the employer involved. ${ }^{13}$ These 1950 yardsticks excluded comparatively little from the Board's orbit; but in 1954, following the Supreme Court's decision on pre-emption in Garner v. Teamsters Union, $A F L,^{14}$ the Board revised its rules $^{16}$ so as to increase considerably the restrictions on its exercise of jurisdiction, ${ }^{16}$ stating: $:{ }^{17}$

\footnotetext{
8 Employee activity may be unprotected against employer interference either because the means used, Elk Lumber Co., 91 N.L.R.B. 333 (1950) (slowdown), or the end sought, Hoover Co. v. NLRB, 191 F.2d 380 (6th Cir. 1951) (employer discrimination), are contrary to some expressed policy. States may probably regulate activity which is unprotected where it involves means which violate notions of fair play. International Union, U.A.W.A., AFL v. Wisconsin Employment Relations Bd., 336 U.S. 245 (1949). But where the state appears to be controlling an activity because its objective is thought improper, the answer is not clear. Compare Garner v. Teamsters Umion, AFL, 346 U.S. 485, 488 (1953) and City Motors v. International Ass'n of Machinists, AFL, 179 Kan. 157, 292 P.2d 1102 (1956) with Weber v. Anheuser-Busch, 348 U.S. 468 (1955), Gamer v. Teamsters Union, AFL, supra at 499, and Milwaukee Boston Store Co. v. Federation of Hosiery Workers, AFL, 269 Wis. 338, 69 N.W.2d 762 (1955).

0 61 STAT. 146 (1947), 26 U.S.C.A. § 160(a) (1956).

10 "Examining the Act in the light of its purpose, and of the circumstances in which it must be apphed, we can perceive no basis for inferring any intention of Congress to make the operation of the Act depend on any particular volume of commerce affected more than that to which courts would apply the maxim de minimus." NLRB v. Fainblatt, 306 U.S. 601, 607 (1939); see also San Diego Ice \& Cold Storage Co., 17 N.I.R.B. 422 (1939).

11 E.g., F. G. Congdon, 74 N.L.R.B. 1081 (1947) (local trucking company) ; Hubby-Reese Co., 72 N.L.R.B. 1404 (1947) (wholesale grocery); S \& R Baking Co., 65 N.L.R.B. 351 (1946) (bakery).

1216 N.L.R.B. ANN. REP. 15 (1952).

13 Hollow Tree Lumber Co., 91 N.L.R.B. 635 (1950) ; N.L.R.B. Press Release, R-342, October $6,1950$.

14346 U.S. 485 (1953). See text at note 24 infra.

15 Breeding Transfer Company, 110 N.L.R.B. 493 (1954); Jonesboro Grain Drying Cooperative, 110 N.L.R.B. 481 (1954).

16 E.g., under the 1954 yardsticks an employer unust sell $\$ 50,000$ worth of goods in interstate commerce as opposed to $\$ 25,000$ under the 1950 rules; or he must supply $\$ 100,000$ worth of goods or services to a firm doing an interstate business as opposed to only $\$ 50,000$ in 1950 .
} 
In making these modifications, we have given due consideration to all of the criteria spelled out by the Board in 1950, including (1) the problem of bringing the caseload of the Board down to inanageable size, (2) the desirability of reducing an extraordinarily large caseload in order that we may give adequate attention to more important cases, (3) the relative importance to the national econoiny of essentially local enterprises as against those having a truly substantial impact on our economy, and (4) overall budgetary policies and limitations. If one of the inevitable consequences of our action is to leave a somewhat larger area for local regulation of disputes, we do not share our colleagues' apparent view that this is a sinister development. We do say, however, that a desire to establish broader State jurisdiction is in no wise a factor in our decision. We are concerned here solely with the problem of defining the limits of our jurisdiction pursuant to the discretionary power vested in us by the Congress.

Unless or until invalidated, ${ }^{18}$ the new yardsticks pose a serious problem for federal-state relations. They create a large area between the Board's yardsticks and its statutory jurisdictional limits in which the Board will not enforce the federal act. In this area-variously known as "no man's land," "twilight zone" or "tidelands" — what is the effect of the TaftHartley Act upon the jurisdiction of state courts and administrative tri-

What proportion of employment relations are removed from the Board's orbit by the new regulations is a matter of some dispute. Estimates range from $1 \%$ by the majority of the Board, Breeding Transfer Co., 110 N.L.R.B. 493, 499 (1954), to between 25 and $33 \frac{1}{3} \%$ by NLRB Member Murdock. Breeding Transfer Co., supra at 508 (dissent).

17 Id. at 497. However, in his dissenting opinion Member Murdock relied on public statements by members of the majority of the Board as evidence that they were motivated, in spite of their denial, by a desire for greater state regulation. Id. at 500 .

18 The Supreme Court has inferentially upheld the Board's power to limit the exercise of its jurisdiction. The Court demed certiorari in Haleston Drug Stores, Inc. v. NLRB, 187 F.2d 418 (9th Cir. 1951), wherein the lower court held that the Board should, on the basis of its yardsticks, refuse to process a complaint issued by the General Counsel for the Board. Haleston Drug Stores, Inc. v. NLRB, 342 U.S. 815 (1951). In NLRB v. Denver Bldg. \& Constr. Trades Council, 341 U.S. 675, 684 (1951), the Court, by way of dicta, stated: "Even when the effect of activities in interstate commerce is sufficient to enable the Board to take jurisdiction of a complaint, the Board sometimes properly declines to do so, stating that the policies of the Act would not be effectuated by its assertion of jurisdiction in that case."

But the Board's discretion in this matter presumably is not absolute. Pederson v. NLRB, 234 F.2d 417 (2d Cir. 1956) (Board cannot properly decline under its 1954 yardsticks to process a complaint against an employer for discriminating against an employee who testified at a Board hearing held under 1950 yardsticks) ; cf. Teamsters Union, AFL v. NLRB, 38 L.R.R.M. 2305 (9th Cir. 1956).

If it could be shown, as Member Murdock argues, that the motives of the Board's majority in estabhishing the yardsticks was to revest states with jurisdiction, then there may be some basis for holding the yardsticks to be an abuse of administrative discretion. For a discussion of this possibility see Roche \& Hanslowe, NLRB Absolutism: A Dogma Revisited, 6 LAB. L.J. 279 (1955). 
bunals ${ }^{19}$ Do the same standards of federal pre-emption apply in this area as in that included within the Board's yardsticks? Or does declination of jurisdiction by the Board permit, as a majority of the Board imply, the "local regulation of disputes"? If so, does the federal act have any effect? May a state, for example, apply the act? Must it do so? May it apply its own law? If so, may that law conflict with the act? These are questions to which the lower courts ${ }^{20}$ and administrative tribunals ${ }^{21}$ have given conflicting answers, and to which the attention of the Supreme Court is urgently required.

The Supreme Court in several instances has taken note of the problem but has never decided it. In Bethlehem Steel Co. v. New York State Labor Relations $B d .^{22}$ it held a state labor board lacked jurisdiction to entertain a petition for representation by a union of foremen even though the NLRB would have declined to entertain the petition. In so holding, the Court noted that the ground for the NLRB's declination rested on a policy that such units were inappropriate, not that the Board would refuse to exercise jurisdiction. The Court said: ${ }^{23}$

${ }^{19}$ For discussion of this problem see Feldblum, Jurisdictional "Tidelands" in Labor Relations, 3 LAB. L.J. 114 (1952); Humphrey, The Changing Jurisdictional Standards of the National Labor Relations Board: Have They Created a Pentmbral Area Between Federal and State Jurisdiction?, 15 FED. B.J. 30 (1955) ; Pollard, Federal Labor Law: Administrative Recession, 6 LAB. L.J. 863 (1935); Whitney, NLRB Jurisdictional Policies and the Federal-State Relotionships, 6 LAB. L.J. 3 (1955) ; Comment, NLRB Jurisdictional Standards and State Jurisdiction, 50 Nw. U.L. Rev. 190 (1955); Note, 65 YAT.E L.J. 86 (1955); see also materials cited in note 60 infra.

${ }^{20}$ In favor of excluding state enforcement: Retail Clerks, AFL v. Your Food Stores, 225 F.2d 659 (10th Cir. 1955) (suit to enjom picketing for union shop by allegedly non-representative union); Universal Car Co. v. International Ass'n of Machinists, AFL, 35 L.R.R.M. 2087 (Mich. 1955) (suit to enjoin picketing for recognition) ; New York State Labor Relations Bd.v. Wags Transp. System, 130 N.Y.S.2d 731 (Sup. Ct. 1954), aff'd, 284 App. Div. 883, 134 N.Y.S.2d 603 (1st Dep't 1954); see also City Motors, Inc. v. International Ass'n Machinists, AFL, 778, 179 Kan. 157, 292 P.2d 1102 (1956) (exclusion in spite of dismissal of the complaint by the Board, but unclear whether the dismissal was on jurisdictional grounds).

Opposed to exclusion: Milk Drivers v. Cream-O-Land Dairy, 39 N.J. Super. 163, 120 A.2d 640 (App. Div. 1956) (suit to enforce collective bargaining contract); Garmon v. San Diego Bldg. Trades Council, 45 Cal. 2d 657, 291 P.2d 1 (1955) (suit to restrain picketing, allegedly by non-representative union, for union shop agreenient) ; Fairlawn Meats, Inc. v. Amalgamated Meat Cutters, 37 L.R.R.M. 2669 (Ohio 1954), appeal dismissed, 164 Ohio St. 285, 130 N.E. 237 (1955) ; Dallas Gen. Drivers v. Jax Beer Co., 276 S.W.2d 384 (Tex. Ct. Civ. App. 1955) (picketing for recognition by non-representative union); see also Wisconsin Employment Relations Bd. v. Local 200, Int'l Brotherhood of Teamsters, AFL, 36 L.R.R.M. 2550 (Wis. 1955) (dicta); Dallas Gen. Drivers v. Wamix Inc., 281 S.W.2d 738 (Tex. Civ. App. 1955) (trial court holding that state court jurisdiction to enjoin secondary picketing on ground employer's business did not neet NLRB yardsticks affirmed on other grounds).

${ }^{21}$ State administrative agencies have held unaminously in favor of their own jurisdiction. Norwich Lumber Co., 36 L.R.R.M. 1500 (Conn. 1955); Walker Motors, 36 L.R.R.M. 1290 (Mich. 1955); Raisch Motors, 35 L.R.R.M. 1631 (N.Y. 1955); Victory Chain, Inc., 34 L.R. R.M. 1664 (N.Y. 1954) ; Cooper-Utter Luniber Co., 34 L.R.R.M. 1287 (Wis. 1954).

22330 U.S. 767 (1946).

$23 \mathrm{Id}$. at 776. 
The election of the National Board to decline jurisdiction in certain types of cases, for budgetary or other reasons, presents a different problem which we do not now decide.

In Garner v. Teamsters Union, $A F L,{ }^{24}$ while holding a state court could not enjoin activities which the Board might hold prohibited by the act, the Supreme Court stated: ${ }^{25}$

Nor is there any suggestion ... that the federal Board would decline to exercise its powers once its jurisdiction was invoked.

Finally, in Building Trades Council v. Kinard Construction Co., ${ }^{26}$ a companion case to Garner, the Supreme Court reversed per curiam a decision by the Supreme Court of Alabama ${ }^{27}$ holding that a state court could act where it appeared from an examination of the Board's yardsticks that the Board would not have asserted jurisdiction. The Supreme Court based its decision, however, on the narrow ground that there was "no clear showing that respondent has applied ... for appropriate rehef, or that it would have been futile to do so...."2s It left open the question, therefore, whether such application or futility would operate to revest states with jurisdiction.

That question cannot reniain unanswered for long, however, and the Supreme Court has recently granted writs of certiorari to review the decisions of two state supreme courts which pose the problem of whether the doctrine of pre-emption prevents state regulation of labor activities where the National Labor Relations Board has declined to assert its statutory jurisdiction. ${ }^{20}$

24346 U.S. 485 (1953).

25 Id. at 488.

26346 U.S. 933 (1953).

27 Kinard Constr. Co. v. Building Trades Council, 258 Ala. 500, 64 So. $2 d 400$ (1953).

28 Building Trades Council v. Kinard Constr. Co., 346 U.S. 933 (1953). The employer in the instant case claimed to purchase only $\$ 75,000$ worth of material per year from outside the state and to utilize only $\$ 500,000$ worth of material annually. The Board's yardsticks required a "direct flow" of material valued at $\$ 500,000$ a year, or an "indirect flow" of material valued at $\$ 1,000,000$ a year.

28 Garmon v. San Diego Bldg. Trades Council, 45 Cal. 2d 657, 291 P.2d 1 (1955); Fairlawn Meats, Inc. v. Amalgamated Meat Cutters, 37 L.R.R.M. 2669 (Ohio 1954), appeal dismissed, 164 Ohio St. 285, 130 N.E.2d 237 (1955). In the Garmon case the California court held that refusal by the Board's regional director on jurisdictional grounds to hold an election among the employees of plaintiff employer was sufficient evidence that the Board would decline to assert its jurisdiction over an unfair labor practice charge against the defendant union. As Justice Carter, joined by Chief Justice Gibson and Justice Traynor, pointed out in an able dissent, however, the employer could have appealed from the refusal to the Board itself, and the appeal might have been sustained. Furthermore, yardstick criteria are not in all ways the same in a "charge" case as in a "representation" case. In the former only, the operation of the charging employer may under some circumstances be considered together with that of a "secondary" employer for determining application of the yardsticks. The evidence as to Board inaction in the Garmon case was, therefore, not conclusive.

In the Fairlawn case there had been no application to the Board. While there was evidence 
The Court has available to it four alternative solutions to the problem of pre-emption posed by these and other cases which may arise in the future. The Court may hold: (1) that the Taft-Hartley Act imposes no restrictions whatever on state regulation of labor relations in the area where the Board has relinquished control; (2) that states may regulate labor relations in this area so long as they do not infringe on activities protected by the act; (3) that states must enforce the federal act in the area of Board inaction; or (4) that the same doctrine of exclusion is applicable to the states in this area as is applicable where the Board has retained control. We propose to consider these alternatives with a view to the design of the act as well as to national labor policy.

I

THE TAFT-HARTLEY ACT IMPOSES NO RESTRICTIONS ON STATE REGULATION OF LABOR RELATIONS IN THE AREA WHERE THE BOARD HAS RELINQUISHED CONTROL

Under this first alternative a state would be free to apply its own law to labor-management relations in the area relinquished by the Board even though that law conflicts with the terms of the federal act. ${ }^{30}$ This position can be supported by either of two hypotheses as to Congressional intent and policy: (a) that Congress saw no reason to pre-empt state action where there is no danger of concurrent exercise of jurisdiction by the Board; or (b) that Congress felt that any reasons for pre-emption that might apply in the area of Board inaction were outweighed by considerations in favor of state regulation. At this point we shall consider primarily the first hypothesis and reserve full consideration of the second until we reach the fourth alternative.

The basis of the first argument is that the only reason why Congress would wish to exclude state regulation from any field is that such regulation might destroy the uniformity imposed by or conflict with the policy of some federal law. The argument is that since the Board in this instance does not assume jurisdiction and does not act, there can be no conflict between state and federal law. In the absence of the danger of non-uniformity

that the Board would probably have not asserted jurisdiction (the employer's operation fell far below the Board's yardsticks), that evidence was probably no greater than in the Kinard case. The trial court rested its decision on the ground that the Board would not act, but the appellate court affirmed on the ground the employer's operation did not "affect interstate commerce."

${ }^{30}$ Some courts appear to accept this proposition, e.g., Garmon v. San Diego Bldg. Trades Council, supra note 29. Although the court in the Garmon case states that there is no conflict with the federal act, and the federal act is enforced, the rationale of the case would seem to permit states to apply their own law or the federal act wherever the Board refuses to assert its jurisdiction. However, including Garmon, there are no decisions which cannot be explained on the basis of some less drastic alternative. 
or conflict, Congress, it may reasonably be assumed, did not intend to preclude state action. ${ }^{31}$

Assuming the validity of this reasoning, it still fails to support the contention that the states should be absolutely free to act where the Board does not. It would not protect against non-umiformity and drastic conflict with federal policy.

Non-uniformity would arise fronl differences in state laws. If no restriction is placed on the power of states to regulate in the area vacated by the Board, an employer doing interstate business falling within that area would be subject to a number of laws undoubtedly differing in character.

The problem of non-uniformity is rendered more acute by the fact that under this first alternative unions and employers would have no practical method of determining whether they were within the Board's yardsticks. This is especially true since the Board has no procedure for rendering declaratory judgments. These yardsticks are constantly changing and always require interpretation by the Board; $;^{32}$ it was for this reason, presumably, that the Supreme Court in the Kinard ${ }^{33}$ case insisted on some evidence of Board declination in addition to the yardsticks themselves. While the Supreme Court would undoubtedly accept Board dismissal of a complaint on yardstick grounds as sufficient evidence that the Board would not act, such a ruling would be difficult to obtain. For example, under this alternative the states are permitted to regulate activities not prohibited by the act. In an action before the Board to determine whether a particular activity is within the scope of the Board's yardsticks, the Board may dismiss on the ground that the complaint states no unfair labor practice under the act rather than on the ground of "jurisdiction."

A more grave objection to permitting states to act without limitation as to industries affecting interstate commerce is that such a solution would allow states to regulate in a manner conflicting with federal policy. Labor law is not comparable to legislation prescribing the side of that road on which a motorist should drive. Congressional policy reaches beyond a desire that

31 "The reason for prohibiting state courts from acting in cases in which the Board has jurisdiction is to obtain uniform application of the substantive rules as expressed by Congress, and to avoid diversities and conflicts likely to result from a variety of local procedures and attitudes toward labor controversies .... There is no conflict of jurisdiction when the federal board determines not to adjudicate the issues." Id. at 662-63, 291 P.2d at 5. Although advancing the argument, it is not clear whether the court adopted our first alternative.

32 "If the jurisdiction of state courts is to depend-not upon the act of Congress and the actual jurisdiction of the NLRB-but upon the day-to-day or month-to-month discretionary exercise of jurisdiction by the Board, dependent upon changing budgetary conditions or upon its economic, social or political views at the moment, then neither the courts nor the litigants can know with any certainty where jurisdiction lies, nor whether in a given case jurisdiction existing at the time of its commencement will continue until its final decision." Universal Car Co. v. International Ass'n of Machinists, AFL, 35 L.R.R.M. 2087, 2098 (Mich. 1955).

33 346 U.S. 933 (1954); see text at note 26 supro. 
all labor-management relations be regulated in the same manner. It rests upon a particular view as to what that regulation ought to be; state regulation which conflicts with that view conflicts with federal labor policy.

Unrestricted state regulation of employee activity in the area vacated by the Board would almost certainly conflict with federal policy in favor of protecting employee concerted activities. Section 7 of the act provides: ${ }^{34}$

Employees shall have the right to self-organization, to form, join, or assist labor organizations, to bargain collectively through representatives of their own choosing, and to engage in other concerted activities for the purpose of collective bargaining or other mutual aid or protection, and shall also have the right to refrain from any or all of such activities except to the extent that such right may be affected by an agreement requiring membership in a labor organization as a condition of employment as authorized in section 8(a) (3).

The Supreme Court has interpreted this section to protect concerted activities, not only against employers through the unfair labor practice provisions of section 8 , but also against states as well. ${ }^{35} \mathrm{~A}$ state may not, by legislation or decision, deprive employees of rights which the section guarantees. Most activity not prohibited by the act is protected by it. ${ }^{30}$ Therefore most existing state regulation which conflicts with the federal act violates this prohibition.

There is no basis in the act for limiting section 7 protection only to cases where the Board might choose to assert its jurisdiction. The Board has jurisdiction to protect section 7 rights only as against private parties; but only the courts have the power to enforce these rights against a state. Furthermore, in certain situations, such as organizational picketing, the Board may not even be afforded the opportunity to decide whether or not the activity is protected. ${ }^{37}$ Possible conflict with Board decision is not, therefore, the test of protection; states are precluded from interfering, not because the Board may act, but because such interference conflicts with the declared policy of section 7 .

Accepting this position, the Supreme Court in the recent case of United Mine Workers v. Arkansas Flooring $\mathrm{Co}^{38}$ held that a state could not enjoin representational picketing, a protected activity, ${ }^{39}$ by a union which had not

3461 StaT. 140 (1947), 29 U.S.C.A. $\$ 157$ (1956).

35 See note 4 supra.

36 See Garner v. Teamsters Union, AFL, 346 U.S. 485, 499 (1953); International Union, U.A.W.A., AFL v. Wisconsin Employment Relations Bd., 336 U.S. 245 (1949).

37 To say that an activity is "protected" means, usually, that the employer will be restrained from discriminating against employees who participate in it. If those who participate in picketing are not employees of those against whom the picketing is directed, there is no way the issue of "protection" can be litigated before the Board.

38351 U.S. 62 (1956).

$39 \mathrm{Id}$. at 75 . 
complied with the act's filing requirements in spite of the fact that, because of such noncompliance, the Board would not protect the umion's activity against the employer. ${ }^{40}$ The Court said: ${ }^{41}$

The industrial relations between the company and its employees nonetheless affect interstate commerce and come within the field occupied by the National Labor Relations Act, as amended. The Labor Board is but an agency through which Congress has authorized certain industrial relations to be supervised and enforced. The Act goes further. The instant employer, employees and union are controlled by its applicable provisions and all courts, state as well as federal, are bound by them.

State regulation of employer activity in the disputed area may also conflict with federal policy. The act contains provisions which guarantee to employers certain rights as against state regulation. For example, section 14(a) provides that: ${ }^{42}$

[N] employer subject to this Act shall be compelled to deem individuals defined herein as supervisors as employees for the purpose of any law, either national or local, relatimg to collective bargaining.

Since the Board could have no part in protecting an employer against a local law requiring him to treat his supervisors as "employees," the sole fact that the Board, because of its yardsticks, will not act is irrelevant to the question whether a state may enforce such a law.

The scope of the Taft-Hartley Act is surely not coextensive with the Board's choice of the area in which it will act. Congress might well have assumed at the time the Wagner Act became law" that the phrase "affecting interstate commerce" was, because of constitutional restrictions, a narrow one. ${ }^{44}$ By the time of the 1947 amendments, ${ }^{45}$ however, it was obvious that the phrase was broader than the area in which the Board asserted its jurisdiction. Yet in these amendments Congress not only reiterated the Board's power to enforce the Act in industries "affecting commerce," but incorporated that phrase in new sections not dependent upon any Board action for their effect. Section 14(a) is one such section. Other examples are section 301, permitting suits for violation of collective bargaining con-

40 Section 10(f) provides in part that no complaint shall be issued pursuant to a charge made by a labor organization unless the organization has filed with the Secretary of Labor copies of its constitution and by-laws and a report showing the details of its internal organization and financial affairs. Section $10(h)$ contains a similar restriction on unions whose officers have not filed non-communist affidavits.

41 United Mine Workers v. Arkansas Oak Flooring Co., 351 U.S. 62,74 (1956). (Emphasis added.)

4261 StaT. 151 (1947), 29 U.S.C.A. \$ 164(a) (1956). (Emphasis added.)

4349 STat. 449 (1935).

44 Initially, employers contended the act could not even reach the nation's major manufacturing concerns. See NLRB v. Jones \& Laughlin Steel Corp., 301 U.S. 1 (1936).

4561 STaT. 140 (1947), 29 U.S.C. \$§ 151-66 (1952). 
tracts; section 302, restricting payments to employee representatives; and section 303, providing for damage suits in the case of activities proscribed as unfair by section 8 (b) (4). In view of the Supreme Court's repeated definition of that phrase, Congress could hardly have intended to permit the Board, by accepting or declining jurisdiction, to fix the scope of the act. ${ }^{40}$

Unrestricted state regulation in the area vacated by the Board, would, therefore, both destroy the uniformity of and conflict with the substance of federal policy. Congress did have good reason to restrict state regulation in that area, and the language of the act makes it clear that, at least with regard to protected activities, Congress has done so. In the absence of very strong reasons for permitting unrestricted state regulation in spite of these obstacles, the first alternative solution to the problem must be rejected.

\section{II}

\section{STATES MAY REGULATE IABOR RELATIONS IN THE AREA WHERE THE BOARD HAS DECLINED TO ACT SO LONG AS THEY DO NOT INFRINGE ON PROTECTED ACTIVITIES}

Since we have concluded that the language and policy of the act, as interpreted by the Supreme Court, apparently preclude state restriction of protected activities in the area not regulated by the Board, the question then arises whether a state may regulate activities which are not protected by the act, either (a) because they are prohibited by it, or (b) because, though not prohibited, they are contrary to its policy or the policy of some other statute. ${ }^{47}$ Even as to the area within the Board's yardsticks, the Supreme Court has not yet decided the status of activities which the act neither protects nor prohibits; therefore, we shall confine our discussion to the issue of state regulation of prohibited activities. ${ }^{48}$

The possibility that the act permits state regulation of prohibited, though not of protected, activities is in many ways an appealing one. It would permit a certain degree of local regulation while at the same time prevent the flagrant intrusions on federal policy that would occur if the state could condemn protected activities. Most of the lower court decisions

46 The Board has always acknowledged that the statutory test of its jurisdiction is different from the restraints it chooses to impose on that jurisdiction. East Newark Realty Corp., 115 N.L.R.B. No. 75 (1956). The federal courts of appeal have held that the Board's "self-imposed rule is not jurisdictional." NLRB v. Daboll, 216 F.2d 143, 144 (9th Cir. 1954); NLRB v. Red Rock Co., 187 F.2d 76 (5th Cir. 1951), cert. denied, 341 U.S. 950 (1951).

47 See note 8 supra.

48 A holding that the act prevents states from regulating activities which are neither prohibited nor protected could be based upon either, or both, of two theories: (1) that by not prohibiting such conduct, Congress intended to leave it to the free play of economic forces; or (2) that the line between these activities and activities which are protected is such a vague one that state regulation of the former would threaten the latter. Sce cases cited note 8 supra. Both these theories are cqually applicable to the area in which the Board has chosen not to act. 
which permit state regulation of labor activities where the Board does not act mvolve cases in which the state courts believed such activity was prohibited under the act. ${ }^{49}$

At the outset we face the question whether the state court which applies a Taft-Hartley prohibition can thus "enforce" federal law, whether the manifest statement of a state court that it is regulating conduct because it amounts to an unfair labor practice under the act serves in itself as a basis for denying the court the power to act. The recent decision of the California Supreme Court in Garmon v. San Diego Bldg. Trades Council ${ }^{50}$ illustrates this problem.

In Garmon a umion picketed an employer over whom the Board apparently would not assert jurisdiction. ${ }^{51}$ The trial court found that the union sought by picketing to obtain the employer's agreement to a umion shop despite the fact that the union did not "represent" his employees. Though such picketing was lawful under previous Califorma decisions, ${ }^{52}$ the court enjoined it on the grounds that the employer was engaged in interstate commerce and that the picketing constituted a violation of the Taft-Hartley Act. A majority of the Supreme Court of California affirmed the trial court's holding that the state court had jurisdiction in view of the Board's declination. ${ }^{53}$ Three dissenting judges argued the state court could not apply the federal law to the situation though they inferred that it could have applied state law..$^{54}$

Since California provides no administrative procedure sucli as that of the act for determining whether a union "represents" employees in an appropriate unit, the decision, in attenupting to enforce the act's proscriptions, is at least questionable. Moreover, it is difficult to conceive how the court can justifiably apply, as it apparently intends, one law to employers whose operations affect interstate commerce and another to those whose opera-

49 See note 20 supra.

50 45 Cal. 2d 657, 291 P.2d 1 (1955).

51 See note 29 supra.

52 McKay v. Retail Automobile Salesmen's Union, 16 Cal. 2d 311, 106 P.2d 373 (1940).

53 The court assumed the California tribunal would have had no jurisdiction if the employer's operation fell within the Board's yardsticks. As to the court's power to grant imjunctive relief, that assumption is justified by the Supreme Court's decision in the Kinard case. Section 14(b), providing that "nothing in this Act shall be construed as authorizing the execution or application of agreements requiring membership in a labor organization as a condition of employment in any State or Territory in which such execution or apphication is prohibited by State or Territorial law," was designed to permit state legislation more restrictive than that of the federal act. 1 NLRB, Legislative HISTORY OF THE LABOR MANAGEMENT RELations ACT or 1947, at 564 (1948). It would therefore have no application in the Garnon context. See Grimes \& Haver, Inc. v. Pollock, 163 Ohio St. 372, 127 N.E.2d 203 (1955). It is not so clear, however, that a state court would have no jurisdiction to award damages within the Board's yardsticks. See note 7 supra.

54 Garmon v. San Diego Bldg. Trades Council, 45 Cal. 2d 657, 667, 291 P.2d 1, 7 (1955). 
tions do not. These considerations probably inspired the dissenting opinions.

So far as federal supremacy is concerned, however, the lack of wisdom of the decision is probably irrelevant. If a state may apply its own law, presumably a state legislature could adopt and apply a statute identical with the federal act; in fact, greater conformity with federal policy would thereby inure. Similarly, nothing in the act, or its policy, prevents a state court from relying upon the unfair practice provisions of the federal act for a definition of a "proper" labor objective at common law. Indeed, the court in the Garmon case at least indicates that it thought it was merely applying earlier California decisions ${ }^{55}$ which imphed that picketing to force a violation of a federal statute was enjoinable under state common law. If, then, the court could have adopted federal policy as its own, the difference between incorporating federal policy into state law and directly "applying" federal law as state law is merely a verbal one, whatever the court's chain of reasoming.

The issue resolves, then, into the question whether Congress intended to leave states free to act in the area abandoned by the Board, whatever law they choose to "apply," so long as they do not tread on activities which the act protects. There are several reasons, both of statutory language and policy, which point to a negative answer.

The first reason lies in the language of section 10(a) of the act. That section provides: ${ }^{50}$

The Board is empowered, as heremafter provided, to prohibit any person from engaging in any unfair labor practice (listed in section 8) affecting commerce. This power shall not be affected by any other means of adjustinent or prevention that has been or may be established by agreement, law, or otherwise: Provided, That the Board is empowered by agreement with any agency of any State or Territory to cede to such agency jurisdiction over any cases in any industry (other than mining, manufacturing, communications, and transportation except where predominately local in character) even though such cases may involve labor disputes affecting commerce, unless the provision of the State or Territorial statute applicable to the determination of such cases by such agency is inconsistent with the corresponding provision of this Act or has received a construction inconsistent therewith.

Congress added the proviso in 1947 in order to overcome the implication of the Supreme Court's decision in the Bethlehem ${ }^{57}$ case that the Board could not cede jurisdiction to a state tribunal. ${ }^{58}$ While Congress permitted

55 E.g., Park \& Tilford Import Corp. v. International Brotherhood of Teamsters, AFL, 27 Cal. 2d 599, 165 P.2d 891 (1946).

5661 StaT. 146 (1947), 29 U.S.C.A. $\$ 160$ (b) (1956).

57 Bethlehem Steel Co. v. New York State Labor Relations Bd., 330 U.S. 767 (1946).

581 NLRB, Legislative History of The Labor Managearent Relations ACt of 1947, at 500 (1948). 
cession of jurisdiction it limited such cession to cases in which there was agreement with a state agency, and then only where the state statute was not inconsistent or had not received an inconsistent construction with corresponding provisions of the act. The implication of this proviso is that the method which is prescribed is the only method by which a state may obtain jurisdiction. ${ }^{69}$

Two techniques have been suggested for escaping the implication that section 10(a) precludes state action without cession. One writer ${ }^{80}$ has suggested that the section applies only to action by a state administrative tribunal and that no cession is necessary to the jurisdiction of a state court. But if such were the case, it would be equally true in that area where the Board is accepting jurisdiction. Yet it is clear that a state court may not "apply" the federal act in such a situation. ${ }^{61}$

The second technique for avoiding the pre-emptive implication of section 10(a) is to contend that in enacting the proviso, Congress had in mind only those industries within the area in which the Board asserts jurisdiction and assumed that the courts would hold that a state tribunal could exercise jurisdiction without cession over the area in which the Board declined to act. In support of this interpretation, it could be said that in a situation in which the Board does not act, its power of enforcement is not "affected by" state regulation. ${ }^{62}$

The legislative and administrative history of section 10(a) appear, however, to defeat such an interpretation. In the first place, Congress had slight basis for assuming the Supreme Court would hold the act to permit state action outside the area of the Board's yardsticks. ${ }^{63}$ The fact that the section does not specify Board inaction as a nieans by which states may ac-

60 See New York State Labor Relations Bd. v. Wags Transp. System, 130 N.Y.S.2d 731 (Sup. Ct. 1954), aff'd, 284 App. Div. 883, 134 N.Y.S.2d 603 (1st Dep't 1954).

Bo Note, 43 GEO. L.J. 67 (1954).

01 Building Trades Council v. Kinard Constr. Co., 346 U.S. 933 (1953).

62 "When jurisdiction is declined by the Board, the legislative mandate that nothing in the Act shall affect the Board's power to enforce the act is not infringed upon." Garmon v. San Diego Bldg. Trades Council, 45 Cal. 2d 657, 664, 291 P.2d 1, 6 (1955).

63 In the Bethlehen case the majority of the Supreme Court reserved the question whether Board declination of jurisdiction would revest the states with jurisdiction. In his dissent Justice Frankfurter, jomed by Justices Murphy and Rutledge, made it clear that in his opinion declination would not have that effect: "I cannot join the Court's opinion because I read it to mean that it is beyond the power of the National Board to agree with State agencies enforcing laws like the Wagner Act to divide, with due regard to local interests, the domain over which Congress has given the National Board abstract discretion but which, practically, cannot be covered by it alone. If such cooperative agreements between State and National Board are barred because the power which Congress has granted to the National Board ousted or superseded State authority, I am unable to see how State authority can revive because Congress has been fit to put the Board on short rations." Bethlehem Steel Co. v. New York State Labor Relations Bd., 330 U.S. 767, 779 (1946). 
quire jurisdiction indicates that Congress intended, therefore, the 10(a) procedure to be exclusive.

In the second place, the phrase "except where predominantly local in character," which qualifies a listing of the industries as to which the Board may not cede jurisdiction, further indicates that Congress intended the cession safeguards to apply even to localized employment relationships. ${ }^{34}$

Finally, there is some evidence that both the Board and Congress have interpreted section 10 (a) as providing the only means by which a state may obtain jurisdiction over an industry affecting interstate commerce. In Punch Press Repair Corp., ${ }^{65}$ the Board stated: ${ }^{00}$

Despite the Board's desire for the greatest possible comity with the State boards, it lacks power under the present statute to divest itself of jurisdiction, except in conformity with Section 10(a) of the amended Act.

And Congress has on several occasions rejected bills which would have permitted states to act where the Board dechnes jurisdiction. ${ }^{67}$

These considerations of course are not conclusive. The failure of Congress to include a provision as to state jurisdiction upon Board inaction or to amend the section later so as to include such a provision can be explained on hypotheses other than an intent to exclude state regulation.

Which hypothesis should be followed depends largely upon an evaluation of the policies involved. If Congress had good reason to exclude state regulation even in the absence of Board action, it would be reasonable to attribute to Congress an intent to do so; if, on the other hand, such exclusion would not further the policy of the act, section 10(a) should probably be interpreted to permit state regulation.

Analysis shows that Congress had at least two good reasons for excluding state regulation even of "prohibited" activities: (1) that state regulation might conflict with the results which might have been reached by the Board had it asserted jurisdiction; (2) that state regulation would violate the policy of the act by permitting its discriminatory application.

64 The Supreme Court has stated: "A proviso of $\$ 10(a)$ authorizes cession of jurisdiction to the states only where the state law is consistent with the federal legislation. This insures that national labor policy will not be thwarted even in the predominantly local enterprises to which the provision applies ...." Amalgamated Ass'n of Street, Electric Railway Employees v. Wisconsin Labor Relations Bd., 340 U.S. 383, 397-98 n.23 (1950).

6589 N.I.R.B. 614 (1950).

B8Id. at 615 .

e7 S. 2650, 83rd Cong., 2d Sess. (1954), S. REp. No. 1211, 83rd Cong., 2d Sess. 1954), would have provided: "Sec. 6(b) (1) The Board, in its discretion, may decline to assert jurisdiction over any labor dispute where, in the opinion of the Board, the effect on commerce is not sufficiently substantial to warrant the exercise of its jurisdiction. (2) Nothing in this Act shall be deemed to prevent or bar any agency, or the courts of any State or Territory, from assuming and asserting jurisdiction over labor disputes over which the Board declines, pursuant to paragraph (1) of this subsection, to assert jurisdiction." See also S. 2218, 83rd Cong., 1st Sess. (1953) ; S. 1264, 83rd Cong., 1st Sess. (1953). 
Conficts in results. The basis of Garner v. Teamsters Union, $A F L{ }^{68}$ and of pre-emption doctrine, is that differences in procedure, remedies, expertise, and outlook among tribunals, especially between administrative and judicial tribunals, may lead to significant differences in ultimate results despite seeming similarity or identity of "substantive law." The premise underlying Garner was that in order to avoid this possible conflict, Congress prevented states from regnlating even activities presumably prohibited by the federal act. ${ }^{69}$

This same reasoning applies to the area in which the Board will not act. While there is no possibility in this area that the Board will actually handle the same case differently than the state tribunal, there is the possibility that had the Board asserted jurisdiction, it would have handled it differently. Thus there is substantial danger of conflict with federal labor policy as conceived by the Board.

The most important instance of such danger lies in the possibility of differences in result between determinations of the Board and those of a state tribunal. Because of its unique administrative procedure and expertise, and because of the vagueness of many of the prohibitions in the federal act, the Board in a significant number of cases may reach different conclusions from those of a state court as to whether a particular activity is prohibited by the act.

This possibility of conflict in result would not be especially serious were it not for the fact that the act protects most activities that it does not prohibit. ${ }^{70}$ Thus, if activities described in section 7 are protected throughout interstate commerce, and not merely where the Board acts, then a state tribunal which enjoins activity which the Board would have found unprohibited is likely to be infringing on rights protected by section 7 . While in certain cases state infringement of protected activities would be obvious to a reviewing court, in others it would be clothed in differences in procedure and outlook which are for the most part unreviewable on the record.

This thin line between prohibited and protected activities, and the dependence of the act in large measure upon the Board for drawing that line was one of the reasons, if not the main one, why the Supreme Court in Garner held state jurisdiction precluded. The Court there stated: ${ }^{71}$

\footnotetext{
as See note 14 infra.

09 "Congress did not merely lay down a substantive rule of law to be enforced by any tribunal competent to apply law generally to the parties. It went on to confine primary interpretation and application of its rules to a specific and specially constituted tribunal and pre. scribed a particular procedure for investigations, complaint and notice, and hearmg and decision, including judicial relief pending a final administrative order. . . A multiplicity of tribunals and a diversity of procedures are quite apt to produce incompatible or conflicting adjudications as are different rules of substantive law." Garner v. Teamsters Union, AFL, 346 U.S. 485,490 (1953).
}

70 See note 36 supra.

71346 U.S. at 499-500. (Emphasis added.) 
The detailed prescription of a procedure for restraint of specified types of picketing would seem to imply that other picketing is to be free of other methods and sources of restraint. For the policy of the National Labor Management Relations Act is not to condemn all picketing, but only that ascertained by prescribed processes to fall within its prohibitions. Otherwise, it is implicit in the Act that the public interest is served by freedom of labor to use the weapon of picketing. For a state to impinge on the area of labor combat designed to be free is quite as much an obstruction of federal policy as if the state were to declare picketing free for purposes or by methods which the federal Act prohibits.

State regulation of activities on the ground that they are prohibited by the act would involve condemnation of activities which have not been "ascertained by the act's prescribed processes to fall within its prohibitions," and which therefore, on the theory of the Garner case, would be protected.

The Garmon case provides an instance of this possibility. The trial court there found the union's object in picketing was to obtain a union shop agreement. The umion, however, claimed the picketing to be "invitational" and directed at the employees only. If the union were correct, its activity enjoyed protection under the act. The Board, had it asserted jurisdiction, might well have agreed with the union; if so, the state court enjoined protected activity.

Similarly, the trial court in Garmon found that the union which engaged in picketing did not "represent" the employees for whom it sought a union shop agreement. If the Board had asserted jurisdiction, it would have held an election to determine that issue; voting would have been by secret ballot; and every effort would have been made to prevent employer interference with free choice. California, however, provides no such election procedure. The trial judge relied only upon the evidence produced in court. ${ }^{72}$ The variance between this judicial procedure and that provided by the Board could substantially affect important rights, and yet differences in results would not, for the most part, be subject to review.

Discrimination. To permit state regulation of prohibited activities would also violate federal labor policy by allowing piecemeal and discrimi-

72 The trial court's finding that the union was not representative was based on two facts: (1) the failure of the union to produce any employees to testify in the union's favor; and (2) the testimony of the foreman, a close relative of the employer, as to employee meetings he attended at which the union was discussed. Transcript of Record, p.380, Garner v. Teamsters Union, AFL, 346 U.S. 485 (1953). As to the first meeting the foreman testified: "Q. What did they decide to do? Did they decide to join the union or not to join it? A. At that time we decided to leave it up to Bill and Stewart, and Max (the employers) whether they wantde the union to enter." Transcript of Record, p. 83. Garner v. Teamsters Union, AFL, supra.

As to the second meeting, the foreman's testimony was as follows: "Q. . . . Did you discuss at the second meeting among yourselves as to whether or not you wanted to join a union? A. No. We decided we didn't want to." Transcript of Record, p. 85. Garner v. Teamsters Union, AFL, supra. 
natory application of the act. While states could regulate prohibited activity, this second alternative would not require them to prohibit all activity which the act proscribes. States would be free to enact legislation embodying only those provisions of Taft-Hartley which restrict union activity. And the courts of those states which rely upon common law to regulate labormanagement relations could, and probably would, apply the common law equivalents of the act's restrictions against unions while leaving employers relatively free of regulation. This is so, not necessarily because of prejudice on the part of judges, though that may be a factor, but because the common law typically contains more restrictions on unions than on employers. States are more likely to restrict union picketing, secondary boycotts, jurisdictional strikes, and the like than to restrain an employer from carrying on anti-union activities or to require him to engage in collective bargaining. Thus, the act's major purpose, to encourage collective bargaining by freely chosen representatives, could be destroyed. In its place, within interstate commerce, a system of jurisprudence could easily arise which once again would place unions in the position they occupied prior to the Waguer Act. ${ }^{73}$ In many ways this would be an even more basic violation of federal labor policy than the possibility of state infringement on protected activities while stating that they are prohibited.

We conclude, therefore, subject to whatever weight is to be given considerations in favor of state regulation, that the second alternative, while it has more merit than the first, must be rejected as contrary both to the language and policy of the statute.

\section{III}

STATES MUST ENFORCE THE FEDERAL ACT IN THE AREA VACATED BY THE BOARD

A third alternative for dealing with this problem is to hold that in the area of Board inaction a state not only may but must enforce the rights and duties created by the federal act. At first glance this appears to be the most reasonable alternative. It would overcome for the most part one of the principal objections to the second alternative- the possibility of discriminatory application of the act. It would msure a high degree of uniformity of federal policy throughout interstate commerce. "Rights" created by the act could be protected, not only against states, but against employers and unions as well. While other objections to the second alternative - the language of section 10(a) and the danger to protected activities-would remain, such objections might well be outweighed if this third alternative is otherwise advantageous.

7349 STAT. 449 (1935). 
But from the standpoint of judicial administration, the third alternative presents crucial disadvantages. First, there is a complete lack of any indication of Congressional intent in its favor. While Congress may, as it has in the past, entrust state courts with concurrent power to enforce a federal statute, ${ }^{74}$ there is little ground for concluding it has done so in the TaftHartley Act. Perhaps an expression of such intent would not be required if the act were one that Congress might have assumed a state judicial tribunal could and would enforce. But the act is clearly not geared to enforcement by a judicial tribunal; it rests for enforcement upon an administrative agency. Two-thirds of the states have not enacted labor relations statutes enforcible by administrative agencies. In view of these facts, the adoption of this alternative would not only call for an exercise of judicial discretion far beyond that which our legal system ordinarily regards as proper, but would also entail intolerable confusion.

For example, at the heart of the act lies the procedure for determining what union, if any, represents the employees in an appropriate unit for purposes of collective bargaining. ${ }^{75}$ If the act is held binding upon state courts, can they, and should they, be required to adopt procedures similar to the federal act such as the provision for an election? In the case of unfair labor practice charges, the act calls for a cease and desist order only after a full hearing. Can and should the Supreme Court require the states to comply with this procedure and abandon the use of the ex parte injunction? If so, can and should they be required, like the Board, to petition the federal courts for enforceinent of their orders? If the answer to these questions is in the affirnative, then we face serious problems, not only of judicial discretion, but of constitutionality. ${ }^{76}$ If the answer is in the negative, the Court would be requiring that states apply only part of the act-a situation which would not only tax the policy-making powers of the Court, but which would also conflict with the policy of the act itself. For these reasons the third alternative must be rejected.

\section{IV}

THE SAME STANDARDS OF EXCLUSION ARE APPLICABLE IN THE AREA OF BOARD INACTION AS ARE APPLICABLE WITHIN THE BOARD'S YARDSTICK

The fourth alternative is the only one not subject to any of the previously discussed drawbacks, but this negative merit must, of course, be

74 See, e.g., Missouri ex rel. St. Louis, B. \& M. Ry. v. Taylor, 266 U.S. 200 (1924) ; Tsang v. Kan, 173 F.2d 204 (9th Cir. 1949); Mid-Continent Pipe Line Co. v. Hargrave, 129 F.2d 655 (10th Cir. 1942).

7561 STAT. 143 (1947), 29 U.S.C.A. § 159 (1956).

76 It seeuns unlikely that Congress could constitutionally compel states to create administrative agencies for the purpose of enforcing federal law. But cf. McKnett v. St. Louis \& S.F. Ry., 292 U.S. 230 (1934) (Congress can prohibit state court from refusing jurisdiction on grounds suit is brought under federal law). 
weighed against the advantages of state regulation. It is conceivable that those advantages could be so great as to overcome the obstacles of policy and statutory language considered above.

There are two considerations in favor of state regulation which must be considered: first, that state rather than federal regulation is appropriate in the disputed area because employment relations are local in character and do not substantially affect interstate commerce; ${ }^{77}$ second, that whether or not state regulation is more appropriate than federal regulation in the disputed area, it is to be preferred to no regulation at all. ${ }^{78}$ Neither of these considerations, however, withstand close analysis, nor are they supported by any language in the act.

State versus federal regulation. While it is implicit in our federal system that the desirability of local control of local problems may outweigh the benefits of uniform regulation, this proposition is questionable when applied to the instant problem for at least two reasons.

First, the public's interest in protecting concerted employee activities against state interference is as great in the area of Board inaction as within the area where the Board does act. It is true that the "effect" of employment relations on commerce may be less in the former splere than in the latter; but the reasons for protecting concerted activities against the state are probably greater. In large, multi-state industries union organization is typically strong; it is in the smaller industries that state interference poses the greatest threat to the establishment of collective bargaining. ${ }^{79}$ Furthermore, federal interest in labor relations as a practical matter extends beyond the effect of labor relations on interstate commerce. Though an effect on commerce is conditional to Congressional power to regulate, the tenor of the act suggests protection of "private" as well as so-called "public" rights; in practice the act is regarded as establishing rights and duties much like those of tort law ${ }^{80}$ The act protects, for example, certain interests of individual workers against the union, ${ }^{81}$ even though interference with those interests could scarcely be said to have a substantial effect on interstate

77 "[A] refusal to accept jurisdiction upon the ground that the issue presented does not sufficiently affect the national welfare to justify the Board's attention, in effect, is a declaration that the national labor policy will not be jeopardized if the state assumes jurisdiction." Garmon v. San Diego Bldg. Trades Council, 45 Cal. 2d 657, 663, 291 P.2d 1, 5 (1955).

78 "Certainly Congress did not intend to deprive a business having only a limited effect on interstate commerce of all protection in a labor-management controversy." Ibid.

70 See Summers, Politics, Policy-Making and the NLRB, 6 Syracuse L. Rev. 93, 102 (1954).

${ }^{80}$ See Roche and Hanslowe, NLRB Absolutism: A Dogna Revisited, 6 LAB. L.J. 279 (1955).

81 E.g, section 7 protects the interests of an employee in refraining from engaging in concerted activities. 
commerce. Emphasis upon the effect of an employment relationship on commerce is, therefore, somewhat formalistic.

Second, the arguments traditionally advanced in favor of local control carry little weiglit in the field of labor relations. Labor problems in the area vacated by the Board are not sucl as require unique local solution. That area includes many industries in whicl national or at least interstate bargaining takes place and in which firms compete for interstate business. ${ }^{82}$ Furthermore, even in those industries in which local bargaining predominates, labor problems do not differ materially fron state to state.

Nor does the subject matter of labor law call for the play of local policies and attitudes. State labor policy frequently does not reflect local attitudes so much as the degree of local labor organization and its consequent political power. Furthermore, certain interests exert considerable pressure on some states, especially those of the South, to adopt legislation restrictive of unions in order to attract new industries. In such a situation it is difficult to sympathize with claims for state regulation.

State regulation versus no regulation. The second contention in favor of state regulation in the Board-abandoned area is that whether or not state regulation is to be preferred to federal in this area, it is at least better than no regulation at all. This is in many ways the most serious argument against the fourth alternative and merits careful consideration.

If the fourth alternative were adopted, and the same standards of preemption were applied outside as are applied within the area encompassed by the Board's yardsticks, then at least for some time labor-management relations "outside the yardsticks" would not be subject to any legal regulation beyond that necessary to preserve peace and order. This would have the obvious disadvantage of leaving unprotected those "rights" which the federal act creates in both employer and employee. But as we have seen, the only way of insuring that those rights be protected is by requiring states to enforce them-an alternative which presents difficulties which almost certainly outweigln its merits.

If the third alternative- that states be required to enforce federal law -is rejected, then the lack of legal regulation which would result from adoption of the fourth alternative must be compared with the kind of legal regulation to be expected under the first and second alternatives, whereby states could regulate respectively all, or all but protected, labor activities.

So far as the first alternative is concerned, the language and scheme of the act make it quite plain that federal labor policy does not permit the sac-

82 See Tumbull, Federal-State Jurisdictional Problems, 7 LAB. L.J. 5 (1956). The author, an economist, concludes that "it is probable that the states are actually regulating a greater area of interstate competition than the federal government is regulating intrastate competition." Id. at 59 . 
rifice of protected activities merely for the sake of having some legal regulation. If any state regulation were to be allowed in the area of Board inaction, it must at least be subject to the limitation of the second alternativethat the states not infringe on activities which the act protects.

Weighing the second solution against the alternative of free competition, the balance appears to lie with the latter. Even leaving section 10(a) and the danger of infringement on protected activities aside, the likelihood of discrimination if states were permitted to regulate activities claimed to be prohibited by the act is sufficient to condemn that course of action.

Economic competition between unions and employers is one kind of "regulation." It is the laissez faire of labor relations. Congress, in an attempt to preserve free collective bargaining while at the same time establishing certain "rules of the game," imposed a bilateral pattern of intervention upon a system of economic competition. This two-pronged control, creating rights and duties for both management and labor, is finely adjusted and carefully intermeshed. The balance it creates is an essential part of federal labor policy. If all or most states had labor relations acts which imposed a similar scheme, the argument in favor of state regulation would be much stronger. But considering the type of regulation that would in most cases result if the second alternative were adopted, it is more reasonable to assume that Congress intended the field of labor relations in interstate commerce to revert, when the Board does not act, to the balancing forces of free competition, rather than to the imbalance which state regulation would certainly create.

This is not to say that laissez faire is the best solution to problems of labor-management relations in this country, but only that it is preferable to unrestricted or discriminatory state regulation. Adoption of the fourth alternative would leave open, in the area presently abandoned by the Board, the possibility of several means of legal regulation, all more compatible with federal labor policy than the first three alternatives.

One of the easiest, and perhaps best, solutions would be for the Board to revise its yardsticks so as to reassert jurisdiction over the area it has vacated. It seems likely that the Board would take such action if the Supreme Court adopted the fourth alternative; if it did not, Congress could compel the Board to do so. If Congress believes greater decentralization of admimistration to be desirable, it could achieve that end by revising the Board's structure so as to delegate greater decision-making authority to regional Boards, with the central Board performing a reviewing function by certiorari.

Another solution would be for states to adopt labor relations acts suffciently similar to the Taft-Hartley Act to qualify for cession under section 10(a). If the present section is too restrictive to permit such a course of 
action, Congress could amend it to make cession requirements more lenient, while still preserving substantial compliance with federal labor policy. Such action, combined with a decision by the Supreme Court that in the absence of cession a state could not regulate labor-management relations in the field abandoned by the Board, might well have the effect of inducing states to adopt up-to-date labor law statutes-a result which, from the standpoint of national policy, would certainly be desirable.

We conclude, therefore, that for the Supreme Court to hold the same standards of pre-emption applicable throughout interstate commerce, regardless of Board policy toward assertion of its jurisdiction, is the best immediate solution to the problem of pre-emption posed by Board inaction. This is so for at least two reasons. First, it is the only available alternative which does not run contrary to the expressed policy of the act. To permit states free reigu in the sphere of Board inaction would violate federal policy in favor of protectimg concerted activities. To permit states to regulate all "unprotected" activities would result in discrimination. And to require states to enforce the act would call for a degree of judicial administration perhaps unconstitutional and certainly unwise. Second, the fourth alternative affords a degree of flexibility in solution absent in the other alternatives. The final approach provides a pragmatic rather than a dogmatic solution. It induces a deliberate control of labor relations in this area by congressional enactment, by state legislation in conformity with the TaftHartley Act, or by Board acceptance of a responsibility which it currently disavows. 